social services. These problems will not disappear merely by changing structures and transferring funds. Kogan's study has shown how, in practice, the customer-contractor principle has been difficult to implement and has been modified pragmatically as specific difficulties have been encountered. What is now required is a clearly articulated and publicly stated strategy for applied research that learns from the past and points confidently to the future. Such a strategy should take account of the difficult, messy, multidisciplinary nature of much of this research; it should seek to nurture its development in appropriate ways, not least through the establishment of reasonable security of tenure and career prospects for senior research staff; and it should articulate the nature of the relationship between customer and contractor, and the ways in which that relationship is expressed. Whether or not the new agreement between the Health Departments and the MRC will lead to more commissioning of health services research by the Council these fundamental issues must be faced soon if there is to remain a core of experienced and motivated researchers capable of tackling the complex research questions thrown up by the policy process.

${ }^{1}$ Office of Health Economics. Health research in England: a topic for debate. London: Office of Health Economics, 1981.

${ }^{2}$ Rothschild, Lord. The organisation and management of government research and development. In: $A$ framework for government research and development. London: HMSO, 1971:1-25.(Cmnd 4814.)

3 Whitehead TP. Before and after the Rothschild Report. In : McLachlan G, ed. Five years after: a review of health care research management after Rothschild. Oxford: Oxford University Press for the Nuffield Provincial Hospitals Trust, 1978: 11-49.

${ }^{4}$ Kogan M, Korman N, Henkel M. Government's commissioning of research a case study. Brunel University: Department of Government, 1980.

5 Public Accounts Committee. First report from the Committee of Public Accounts. London: HMSO, 1979. (HC 173.)

${ }^{6}$ Anonymous. Commissioning research. Lancet 1981 ; i :312.

\section{The senile amyloidoses}

Amyloid is a fibrillar protein of variable chemical composition. In the generalised secondary amyloidosis that may complicate chronic suppurative, tuberculous, or rheumatoid lesions a distinctive protein called amyloid fibril protein $\mathrm{A}$ is laid down in the tissues. In primary amyloidosis, which may occur either as a localised deposit or in a generalised distribution and is sometimes associated with multiple myeloma, the protein consists of the light chains of an immunoglobulin molecule, and is called $A L \lambda$ or $A L x$ depending on the antigenic specificity of the light chain. In both types of amyloidosis, whether primary or secondary, all the fibrils in any single individual share an identical chemical composition irrespective of their origin. A third chemically distinct type of protein is found in the stroma of some tumours of endocrine origin, notably the medullary carcinoma of the thyroid. ${ }^{12}$

Amyloid may also be laid down as part of the aging process. Such deposits are common in the heart ${ }^{3-6}$-though minor degrees of amyloid tend to be overlooked unless specially sought and shown up by specific histochemical stains-and they are also found in the pancreas and brain. Senile amyloid has generally been assumed to be a single chemical entity in any one individual irrespective of its site of origin. A recent review article by Cornwell and Westermark ${ }^{7}$ has shown, however, that two distinct varieties of amyloidosis affect the aging heart. The more common is a symptomless condition which affects only the atria and is called isolated atrial amyloid. The better known but less common generalised senile cardiac amyloidosis affects both atria and ventricles. While usually confined to the heart, it may also affect the great vessels, the lungs, and the vessels supplying other organs. Senile cardiac amyloidosis rarely causes symptoms but occasionally leads to cardiac enlargement and failure-though far less frequently than primary amyloidosis affecting the heart. The protein in senile cardiac amyloidosis is unique and is quite distinct from that found in isolated atrial amyloid.

Amyloid affecting the islets of Langerhans is commonly seen in the aging pancreas, especially in diabetes mellitus. Its chemical structure is not known, but it is probably produced by the $\beta$ cells and may be a polymerisation product of a portion of proinsulin. It is antigenically distinct from other types of amyloid. Amyloid of the islets does not appear to cause diabetes mellitus, being the result rather than the cause of $\beta$-cell dysfunction. ${ }^{8}{ }^{9}$

A third type of amyloid is found in the characteristic cortical plaques of Alzheimer's disease and of senile dementia of the Alzheimer type. It is also deposited in the vessels of the brain and meninges, where it is called congophilic angiopathy after the orange colour that congo red imparts to histological preparations of amyloid. Once more, this type of amyloid is antigenically distinct but its chemical nature is unknown. Senile amyloid is probably a secondary phenomenon rather than the cause of the dementia. ${ }^{10}$

Senile amyloidosis, therefore, includes several distinct conditions which share some features common to all forms of amyloidosis but, nevertheless, are each unique in tissue localisation and protein components. There are also ultrastructural differences. The preferable term should be the senile amyloidoses. Clinically they do not usually produce direct effects, but much more still needs to be known about their mode of production and their effect on the function of the organ where they are laid down.

${ }^{1}$ Sletten K, Westermark P, Natvig JB. Characterisation of amyloid fibril proteins from medullary carcinoma of the thyroid. $\mathcal{F} \operatorname{Exp} M e d 1976 ; 143$ : 993-8.

${ }^{2}$ Westermark P, Grimelius L, Polak JM, et al. Amyloid in polypeptide hormone-producing tumors. Lab Invest 1977;37:212-5.

${ }^{3}$ Pomerance A. The pathology of senile cardiac amyloidosis. Fournal of Pathology and Bacteriology 1966;91:357-67.

4 Schwartz P. Cardiovascular amyloidosis in the aged. Geriatrics $1969 ; 24$ 81-97.

5 Wright JR, Calkins E. Amyloid in the aged heart: frequency and clinical significance. F Am Geriatr Soc 1975;23:97-103.

${ }^{6}$ Hodkinson HM, Pomerance A. The clinical significance of senile cardiac amyloidosis: a prospective clinico-pathological study. $Q \mathcal{F}$ Med 1977 ; 46:381-7.

7 Cornwell GG, Westermark P. Senile amyloidosis : a protean manifestation of the aging process. $\mathcal{F}$ Clin Pathol 1980;33:1146-52.

${ }^{8}$ Westermark P, Grimelius L. The pancreatic islet cells in insular amyloidosis in human diabetic and non-diabetic adults. Acta Pathol Microbiol Scand $(A)$ 1973;81:291-300.

9 Westermark $\mathrm{P}$, Wilander $\mathrm{E}$. The influence of amyloid deposits on the isle volume in maturity onset diabetes mellitus. Diabetologia $1978 ; 15: 417-21$.

${ }^{10}$ Glenner GG. Current knowledge of amyloid deposits as applied to senile plaques and congophilic angiopathy. In: Katzman R, Terry RD, eds. Alzheimer's disease, senile dementia and related disorders. New York: Raven Press, 1978:493-502. 